\title{
Lawyers, Judges, and the Obstinate State: The French Case and an Agenda for Comparative Politics
}

\author{
Tommaso Pavone \\ Postdoctoral Fellow, PluriCourts Centre at the University of Oslo \\ tommaso.pavone@jus.uio.no \\ September 8, 2020
}

\begin{abstract}
In the field of comparative politics, France is often taken to exemplify the resilience of the centralized modern state. Stanley Hoffmann popularized this thesis by highlighting the French state's "obstinacy" despite postwar reform efforts. This article revisits Hoffmann's obstinate state thesis by tracing how lawyers and judges shaped French political development. I demonstrate that continuity in French officials' claims to centralized power belie a deeper story of how legal actors catalyze institutional change in unlikely places: In civil law countries without a history of judicial review, in authoritarian regimes without regard for judicial independence, and in seemingly monolithic states without much room for democratic self-governance. These findings compel a comparative research agenda placing lawyers and judges at the center of the study of political development.
\end{abstract}

Key words:

Political development, governance, political liberalism, judicial politics, legal mobilization, European integration, institutional change 


\section{Revisiting the "Obstinate State" in France - and Beyond}

In 1966, Stanley Hoffmann posed perhaps the most fertile question of his long career as a leading political scientist and public intellectual: Was the modern state generally - and in Europe specifically - "obstinate or obsolete?" Two biographical factors made this the "critical issue for every student of world order" (Hoffmann 1966, 862). The first was Hoffmann's survival of state-perpetrated violence during WWII, which forced him and his mother to flee the French capital in May 1940 "two days before the Germans entered Paris." "World politics forced themselves on me," Hoffmann recalled, hence he looked to efforts to create a supranational polity in Europe with skeptical anticipation (Hoffmann 1991, 3-4; 1966, 863). The second was Hoffmann's belief that France is a prism to make sense of world politics. When a festschrift was organized in his honor, Hoffmann "insisted" that at least "half of the essays concentrate on France" (Miller \& Joseph Smith 1991, xi). Hoffmann's devotion to French politics focused his gaze on the state, that "inchoate, economically absurd, administratively ramshackle, and impotent yet dangerous" object (Miller \& Joseph Smith 1991, xi). It also nurtured a "less optimistic" view of efforts to transform it or move "beyond the nation-state" (Hoffmann 1966, 863). For as Hoffmann was putting pen to paper, the "force of General de Gaulle" was imposing "a change in French policy from ambivalence toward [European] integration to outright hostility" (Hoffman 1966, 872, 895). Charles de Gaulle's France exemplified the obstinate state, warts and all, while the continuity of sovereigntist foreign policy testified to its endurance (Hoffmann 1987; 1991, 6-7).

Hoffmann's writings inspired his students to study intergovernmental policymaking in Europe (ex. Moravcsik 1991; 1994; 1998) and anticipated historical institutionalist theories of state resilience and path dependence (ex. Pierson 1994; 2000). Yet for all their theoretical fertility, empirical depth, and prescience, this article demonstrates that they also contained some blind spots (though ones hardly of Hoffmann's own making). In turn, these blind spots bear important implications for how "France as a case" (Fredette, this issue) ought to inform the study of comparative political development.

First, the geocentrism of French state builders and de Gaulle's rhetoric of "grandeur" pulled Hoffmann towards executive-driven "high politics" and away from more incremental, technocratic, and bottom-up forms of policymaking (Hoffmann 1966, 874). Hoffmann dismissed Jean Monnet's plan to unite European states via technocratic engrenage (Featherstone 1994, 154-156) and functionalist theorists of transnational integration like Ernst Hass (Haas 1958): Modern governance would continue to be dictated by executive actors at the helm of obstinate states. While he had good reason to doubt the teleologies of his interlocutors (Moravcsik 1998, 16-17), Hoffmann understated how high politics 
can conceal important struggles for institutional change bubbling up within states themselves. Relatedly, although Hoffmann never shied from critiquing the state, he did not challenge French statesmen's claims to centralized power: The "Executive," Hoffmann declared, is "the prime decisionmaking force in every state" (Hoffmann 1966, 876). To be sure, from Louis XIV proclaiming "I am the state" to Baron Haussmann extolling "our country, the most 'one' in the whole world" (Weber 1976, 9), French state builders have long "fashioned an ideology of centralized power," and political scientists have underscored the French bureaucracy's "reluctan[ce] to see itself in a less rigidly centralized posture" (Suleiman 1974, 20, 37). Yet this ideology has historically belied an "inescapable" reality of local diversity, self-governance, and political fragmentation (Weber 1976, 9). Even behind de Gaulle's imperial presidency lay a less coherent state, one that was in flux and increasingly at war with itself.

This article adopts this alternative vantage point, one that sees the politics of the French state "not as a tightly integrated unitary system, but as a world of contradictory pressures and tensions... desires to maintain the status quo that co-exist with the same persons with desires for change" (Berger 2009, 397; Vail 2004). Abandoning Hoffmann's (1991, 7) "unit-level" focus for an "actor-centered approach" (Saurugger 2016), I argue that the political struggles most disharmonious with Hoffmann's obstinate state thesis lie squarely with the evolving politics of French lawyers and judges. Although Hoffmann was trained as a lawyer, he took his cues from de Gaulle, for whom law and courts were subservient to the state and its executive power (Moeschel 2019). Yet France has actually stirred theory-building amongst socio-legal and judicial politics scholars precisely because it represents a surprising story of bottom-up agency and institutional change (Brouard 2016; Bleich 2018). If French geopolitics compelled Hoffmann to grapple with the state's resilience, then French legal politics - "the use and promotion of legal tools, practices, arrangements, and resources to achieve political" ends (Massoud 2013, 24) - reveal how legal professionals can work to tortuously reform even the most stubborn of states in the most unlikely of places.

A study of French legal politics not only helps us challenge Hoffmann's obstinate state thesis; it is also a springboard for a comparative research agenda that synthesizes two literatures: On lawyers and struggles for political liberalism, and on the judicialization of politics in Europe and beyond. Although these research streams were both inspired by the French historical experience, disciplinary boundaries have hitherto prevented a theoretical synthesis: As historical sociologists focused principally on the politics of lawyers, political scientists devoted themselves primarily to the politics of courts. Given what Max Weber would have described as "elective affinities" between these research 
streams (Howe 1978), I identify how these literatures complement one another, jointly speak to the fate of the modern state, and open fruitful pathways for future comparative research.

The rest of the article follows in Hoffmann's footsteps and is comprised of three sections ("for Stanley," Michael Doyle $(2009,424)$ observed, "everything comes in threes"). In Section II I trace the history of collective action by French lawyers who sought to moderate state power and safeguard civil liberties. These findings excited the comparative imagination by demonstrating that political lawyering can catalyze institutional change and bolster local self-governance in the absence of a moderate or liberal-democratic state. Yet at the same time, studies of French lawyers ignored how their politics intersected with the rise of judicial policymaking in the nascent European Union. Section III demonstrates that despite a republican history of opposition to judicial review, the French state became a terroir for the judicialization of politics, particularly as national judges began soliciting the European Court of Justice to challenge domestic policy. France once again inspired a comparative research agenda, exemplifying how judicialization can take root even in centralized civil law states lacking a history of judicial review. Yet on the flip side, this literature overlooked how lawyers had provided a decisive push for judicialization, with the goal of embedding the French state in nascent transnational polity. Section IV thus fuses these two research streams together, concluding that alliances between lawyers and judges constitute powerful catalysts of governance reforms and political development. Finally, Section V concludes by highlighting the broader theoretical significance of the French case: By testifying to how legal politics in a single case can speak to broader debates in the field of comparative politics, the French historical experience highlights what the field stands to gain by affording greater pride of place to in-depth studies of legal actors.

\section{Liberalizing the State: The Surprising Political Agency of Lawyers}

It is not hard to see why Hoffmann did not see French avocats as agents of state reform, despite having studied law at Sciences Po. In the 200-year post-revolutionary history of French law schools, nobody had yet conducted a political history of the legal profession. The scant comparative scholarship mentioning French lawyers accorded them no political agency and little room for collective action. They were "orphans of French historiography" (Burrage 1999, 1083) subjected to uncharitable comparisons with Britain and the US, where lawyers pre-dated a consolidated state and thus played a more conspicuous role in its formation. French lawyers were collapsed into "state-centered approaches" portraying them as mere byproducts of top-down processes of bureaucratic consolidation (Rueschemeyer 1986, 433-434, 444). If, as Tocqueville (2003, 254-255) first asserted, 
Anglo-Saxon lawyers made states in their own image, it was argued that the French state forged lawyers to serve its need for rationalized rule.

All of this changed with the path-breaking scholarship of sociologist Lucien Karpik and a rising cohort of political historians. In a magisterial historical analysis, Karpik demonstrated how lawyers' struggle for spokesmanship over civil society and commitments to political liberalism cast fingerprints all over the rise of the modern French state (Karpik 1988; 1995). It was a slow and tenuous process, having taken four hundred years for lawyers to escape the grips of the kings who controlled their ability to practice and left them at the whim of the "venal but proud magistrates of the parlements" (Burrage 1999, 1086). Following a series of strikes in the 1700s that ground judicial proceedings to a halt, lawyers successfully organized into local bar associations insulated from royal meddling, whose leaders (the battonniers) were elected attorneys themselves. The French ordres des avocats became the first secular and self-governing bodies outside of the state.

The immediate pre-revolutionary period also witnessed another crucial development. The private correspondence of lawyers reveals that they were increasingly involved in politics beyond the ordres. Parisian lawyers in particular were attuned to on-the-ground public opinion: They actively sought and documented information about the ways that "the common people" criticized the monarchy (Darnton 2010, 118-121). Others covertly handed dissident poems to chansonniers in the streets, who could diffuse political invective beyond the literate elite (Darnton 2010, 20-21, 52). Yet lawyers were hoisted by their own petard as their increasing prominence was suddenly wiped out with the storming of the Bastille. Revolutionaries saw lawyers' politics as primarily serving "the nobility [in] seeking leverage against the Crown" (Scheingold 1999, 1068; Bell 1997, 71-75) and, "as in many utopias, one of the[ir] objectives...was to make lawyers unnecessary" by establishing a system of popular justice (Merryman \& Perez-Perdomo 2007, 29). The Revolution swept away the Paris bar's governing council and decimated its membership to no more than a couple dozen survivors (Karpik 1988, 710). While Napoleon reinstated the bar in 1810 it was a shadow of its former self, prostrated before state officials who meddled routinely in its governance operations (Karpik 1988, 716).

This menial state of affairs was upended by the so-called "lawyers' revolution" of July 1830. Attorneys drafted polemics and took to the streets to overthrow King Charles $\mathrm{X}$ in favor of Louis Philippe. In turn, Louis Philippe appointed Parisian attorneys to ministerial positions, restored the independence of the bar, and reinstated lawyers' right to elect their bâtonniers (Karpik 1999, 121; Karpik 1988, 712). As the Second Empire crumbled in 1870, lawyers continued their political ascendance: The Third Republic was proclaimed by two leading lawyers, Jules Favre and Léon Gambetta, while a 
third attorney, Jules Grévy, soon become President and fiercely opposed calls for reinstating the monarchy (Karpik 1999, 119-120).

The political mobilization of the French bar not only witnessed "its march toward political power." Rather, it proved Janus-faced, with lawyers simultaneously securing their footing within civil society via their outspoken "defense of liberal legality" (Karpik 1988, 712-713). As covert political clubs and dissident newspapers mounted increasingly fierce "assaults upon the monarchy" throughout the Second Empire (Ledre 1960), they became favorite targets of state prosecution and lawyers' passionate legal defense. Even royalist lawyers broke with their partisan affiliations to defend political activists. In the 1864 "Trial of Thirteen" (Le Procès des Treize) against several republican radicals, PierreAntoine Berryer - a renowned orator, lawyer, and head of the Legitimist Party - gave voice to these liberal commitments in his celebrated defense: "I am well aware that this committee cherishes the republican idea to which I am profoundly opposed... it is because of my attachment to these constitutional principles, to these political freedoms... I want their freedom because it is the guarantee of my own... what I am protecting is your right to cherish an idea, to hold a conviction, to support it, defend it and attempt to make it prevail" (quoted in Karpik 1999, 125-126). In these ways, lawyers' legal politics advanced the "struggle for liberal democracy and contributed more to it than any other identifiable group" (Burrage 1999, 1094).

By the dawn of the $20^{\text {th }}$ century French lawyers increasingly invoked the tribunal of public opinion, thus helping to constitute it as a collective interest whose rights they were best positioned to protect (Scheingold 1999, 1069). Yet lawyers had it both ways, embodying the contradictory coevolutions of democratic self-governance and state-building unfolding in the shadows of past claims to absolute rule. That is, legal professionals also increasingly formed the "ruling elite" of the consolidating French state, comprising a quarter of all executive leadership positions and a similar proportion of Parliamentary seats during the Third Republic (Karpik 1999, 135). Thus lawyers not only asserted themselves as representatives of the public in civil society: They also became the public's official representatives in the institutions of a modernizing state.

Lawyers' political mobilization was combined with a stubborn "divorce" from the capitalist market, a disavowal that only broke down after WWII (Burrage 1999, 1085). The Paris bar denied membership to any lawyer serving as a "business agent," and these restrictions survived in diluted form until 1971 (Karpik 1988, 718-719). Attempts to emulate the Anglo-Saxon corporate law firm model were banned: Only in 1972 did lawyers gain the right to form partnerships comprising more than five members (Abel 1988, 19-20). And it was only in a major reform in 1990 that the market 
model was embraced and all obstacles to the agglomeration into big law firms were banished (Burrage 1999, 1107). With "the non-political, business bar" (Bell 2000, 748) coming of age alongside the rise of Gaullist high politics, lawyers' struggles for political liberalism seemed to fade into memory - a misleading point to which I shall return shortly.

These findings about French lawyers sparked a new research agenda that was comparatively engaged and global in scope (Halliday and Karpik 1997; Halliday, Karpik, and Feeley 2007). Karpik had demonstrated that even in a country presumed to exemplify state-directed political development, lawyers had decisively contributed to "politics writ large," meaning "the politics of the nation-state or of the groups and politics that determine its policies and their implementation" (Halliday and Karpik 1997: 3). They did not tie themselves to particular rights causes - as was the case with the "cause lawyers" of the American civil rights movement and the UK labor movement (Sarat and Scheingold 2006) - or become servile agents of the market. Rather, they were "political lawyers" who thought institutionally and fought for a moderate state with an independent judiciary capable of preserving basic civic freedoms and ensuring a minimal degree of self-governance (Karpik 2007).

The French case thus suggested that even in authoritarian regimes, lawyers could still work their discretion as state-society intermediaries to shape politics, often with a liberal bent. This insight inspired scholars to probe the politics of lawyers from Hong Kong and mainland China (Tam 2013; Stern 2011; Liu and Halliday 2016) to Egypt and Venezuela (Moustafa 2007a; Perez-Perdomo 2007), often with complementary findings. It turns out that Tocqueville's American lawyers had little in common with their counterparts in these parts of the world, where state apparatuses had histories of claiming absolute authority. Karpik's French lawyers, on the other hand, excited the comparative imagination, because their legal politics began in the absence of a moderate or liberal-democratic state.

Yet ironically, Karpik concluded his research on French lawyers in a way that aligned with Hoffmann's emphasis on the preeminence of government high politics in sustaining the post-war state. By focusing on the increasing market capture of the legal profession, Karpik suggested a declining role for lawyers in shaping the course of French political development. If the state was no longer threatened by the disruptions of legal politics, then perhaps it was indeed becoming obstinate after all.

This conclusion is incorrect, and it reveals one of the shortcomings of the literature on the lawyers and political liberalism: Its lackluster engagement with the burgeoning scholarship on the judicialization of politics - including in the domain of high or "mega-politics" (Hirschl 2008a; 2008b) of greatest interest to Hoffmann. This scholarship was also inspired by France, and it demonstrates 
that if postwar French lawyers were constrained by market pressures, they also stood to be empowered by the emergence of a new, European "legal opportunity structure" (Hilson 2002; Vanhala 2012; 2018). This opportunity structure took the form of a nascent transnational network of increasingly policydriven courts under the auspices of the European Court of Justice (ECJ) - the supreme court of the nascent European Community. As we will see, far from retiring from politics, French lawyers had gained a new political raison d'être.

\section{Judicializing the State: The Surprising Political Agency of Judges}

Just as France seemed an unlikely case for lawyer-driven political development, so too did it constitute what comparativists would call a "least-likely case" for the judicialization of politics (Eckstein 1975, 113-123). The French Revolution had targeted the "judicial aristocracy" with the same zeal it had directed at the bar (Merryman \& Perez-Perdomo 2007, 17). Revolutionaries entrenched an ideology hailing legislative codification and condemning a gouvernement des judges, one that lowered judges to the status of expert clerks and was diffused across Europe by the Code Napoléon (Merryman \& PerezPerdomo 2007, 29-30). As the inheritor of this civil law tradition, de Gaulle interpreted it as legitimating executive power and judicial subservience. This was captured by some of his favorite aphorisms, like "in France the only Supreme Court is the people," and "first France, then the State, and then... the law" (Moeschel 2019, 291).

Given this context, it is understandable that scholars of France - Hoffmann included devoted little attention to judicial politics through the 1980s (Stone 1992, 6; Brouard 2010, 73). When the French Constitutional Council was created in 1958, it was limited to exercising ex ante review of proposed legislation, and in any case de Gaulle quickly packed it with loyalists. French legal scholars decried the strategy as akin to "the 'entrenchment' of the federalists in the U.S. Supreme Court at the turn of the eighteenth century," while socialist politicians chastised the Council as "servile" (Stone 1992: 51-52). But it was not just the Council that seemed destined to function as an obedient "defender of the executive" (Stone 1992: 61). The supreme administrative court - the Council of State - was also comprised almost exclusively of Gaullists trained at the École Nationale d'Administration (ENA), which was founded by de Gaulle and whose curriculum taught the values of bureaucratic hierarchy (Neville Brown et al. 1998, 38; Biland \& Vanneuville 2012). When in 1962 the Council dared to rule that de Gaulle's creation of a military tribunal in Algeria overstepped his Presidential powers, de Gaulle had a government commission "threaten to do away with the [Council] altogether" (Alter 2001, 138). As for 
dissident senior judges in the civil courts, de Gaulle forced them to retire by lowering the judicial retirement age (Moeschel 2019).

And yet in this most hostile of terroirs, "France has provided one of the best-known case studies of judicialization" (Brouard 2016, 227). In this instance, it was Alec Stone Sweet who played the role of pioneering analyst, achieving for the study of judges what Karpik accomplished for the study of lawyers. The novelty of this effort is evidenced by the fact that a lexicon had to be invented to describe the increasing role of French courts in state policymaking: Thankfully, the clunky language of "juridicisation" (Stone 1989) was soon abandoned by borrowing "the judicialization of politics" from Carl Schmitt (Stone 1992, 253).

Stone Sweet set his sights on an unlikely target: The Constitutional Council. Subservient during de Gaulle's reign in the 1960s, in 1974 a consequential reform enabled any 60 members of either the National Assembly or Senate to activate the Council's review of the constitutionality of proposed legislation. As the Gaullist grip of Parliament (and the Council) began to loosen and give way to increasing partisan conflict, the Council was asked to review "virtually every major piece of legislation" by the political opposition (Stone 1989, 14-16). With the Council striking down proposed ordinary legislation at a rate three times higher than the powerful German Constitutional Court (Brouard 2016, 230), legislative policymaking in the French Parliament was increasingly "self-limited" and "correctively revised" to avoid an adverse judgement (Stone 1989, 16, 28). Once the Council's jurisdiction was expanded in 2010 to encompass concrete disputes arising under enacted legislation, a pattern of "opposition-induced constitutional politics" gave way to "expanded constitutional politics" as individual litigants and national courts began petitioning the Council (Brouard 2016, 228-231).

Stone Sweet's discovery that judicial politics and a gouvernement des juges had been "born" in France (Stone 1992: 102) opened the door for other scholars probing how European integration was fueling this process. Most prominently, Karen Alter (1996) argued that French judges were increasingly invoking European law to exercise judicial review powers historically denied to them by the obstinate state. In 1963 and 1964, the European Court of Justice rendered two path-breaking rulings holding that the laws of the fledgling European Community were not only supreme over conflicting state laws, but could be directly invoked by national courts to disapply Parliamentary legislation. ${ }^{1}$ Any judge who doubted the conformity of legislation or supreme court decisions in the cases before them was empowered by Article 177 of the 1957 Treaty of Rome to refer the case to the ECJ for an authoritative judgement. Alter demonstrated via in-depth interviews and archival research that this "preliminary reference procedure" was increasingly being used by rebellious lower courts to 
challenge state policies and even to circumvent their judicial hierarchy: "When a lower court did not like what it thought one parent (a higher national court) would say... It would ask the other parent (the ECJ)" (Alter 1996, 466-467).

Alter thus built on Stone Sweet's insight that in the domain of judicial policymaking, the French state was hardly behaving like a unitary actor with a tightly integrated hierarchy. Rather, it was increasingly beset by horizontal and bottom-up struggles over the scope of institutional change: The conflicts between the Constitutional Council and Parliament, and the "competition-between-courts dynamic" unleashed by lower courts' dialogue with the ECJ, were a case in point (Alter 1996, 467).

To be sure, the obstinate state and its Gaullist contingents fiercely resisted judicialization. Increasingly concerned about the European Court's influence over French judges, in 1968 de Gaulle proposed to strip the ECJ of jurisdiction to hear referrals from lower national courts, while allowing larger member states (i.e. France) to pack it with additional judges. Both proposals were rejected by other member states (Bernier 2018, 162). As a result, the Gaullists turned their sights inward. The Council of State - having learned its lesson from de Gaulle's threat to disband it if it did not fall in line - collaborated with the Ministry of Interior to block lower administrative courts from soliciting the ECJ. In the infamous 1978 Cohn Bendit case concerning the expulsion of a student leader of the May 1968 protests, the student activist brought suit before the Administrative Court of Paris alleging that the Ministry's expulsion violated a European free movement directive. The Paris judges tried to solicit the ECJ, but their referral never made it: The Ministry blocked transmission and appealed to the Council of State, which quashed the reference and issued a "declaration of war" claiming that European directives did not have direct effect (Alter 2001, 155). And in 1979 - after the Court of Cassation and some lower civil courts had challenged domestic policies by soliciting the ECJ - the Gaullists introduced an amendment in the National Assembly that would have made it illegal for judges to enforce the supremacy of European law (Alter 2001, 238; Bernier 2018, 145, 244). Two prominent Gaullists - Jean Foyer and Michel Debré - followed-up by proposing a resolution declaring that the ECJ "has become as illegitimate... as the Vichy government" (Rasmussen 1986, 350-353).

Neither the amendment nor resolution ended up passing, because in 1981 the socialists came to power and François Mitterrand assumed the presidency. The contested significance of this political shift is instructive. With his gaze set on the high politics of foreign policy, Hoffmann argued that it was hardly a turning point: In Mitterrand he saw continuity and sovereigntism, or "Gaullism by any other name" (Hoffmann 1987). But in the domain of French judicial politics, Mitterand's rise to power was nothing short of what historical institutionalists would call a "critical juncture" (Capoccia and 
Kelemen 2007). The socialists were nowhere near as averse to judicial policymaking and the ECJ as de Gaulle had been, but so long as the Gaullists held "political control of the French judiciary," even the most rebellious of judges were "unsuccessful in having a truly positive impact on the French reception of European law" (Davies and Rasmussen 2012, 313; Bernier 2018). Only "as the power of Gaullist parties weakened" did the obstinacy of the French state succumb to the forces of transnational judicialization (Alter 2001, 125). By 1989 even the Council of State declared defeat, holding in its Nicolo decision that "the era of unconditional supremacy of internal law is now over" (Alter 1996, 469).

Once again, France became a paradigmatic case of the judicialization of politics that inspired comparative analyses not only in other EU member states (ex. Alter 2001; Conant 2002; Cichowski 2007; Kelemen 2011; Kelemen \& Pavone 2018; Pavone \& Kelemen 2019), but even spanning other continents (ex. Ginsburg 2003; Alter \& Helfer 2017). The French case inspired theory building because it demonstrated that judicialization can take root even civil law countries with strong states - provided that this development does not directly conflict with the interests of the dominant partisan coalition. Therefore, judicial policymaking is not bound to countries influenced by the common law tradition of judicial review and "adversarial legalism" (Kagan 2001).

Yet just as the research on political lawyering had insufficiently taken the judicialization of politics into account, so too did scholars stressing the judicialization of the French state neglect to embed judges within a broader complex of trained professionals (Halliday et al. 2007) who worked to "Europeanize" states (Saurugger 2016) by embedding them within a burgeoning "transnational legal field" (Vauchez \& de Witte 2013). The disciplinary divides separating sociological studies of lawyers and political studies of judges appear to have inhibited this theoretical synthesis - a political sociology of lawyers, judges, and the French state with comparative ambition. What could this synthesis look like?

\section{Lawyers, Judges, and Comparative Political Development}

While a comparative political sociology of modern states, lawyers and judges remains lacking, a few rehearsals in this direction have emerged over the past few years. This intellectual endeavor has its own pioneers, with Antoine Vauchez front-and-center. Drawing on Pierre Bourdieu's field theory (Bourdieu 1986), Vauchez has made the case that transnationally-oriented lawyers and judges in France and across EU member states constitute "one of the essential spaces where the government of Europe is being shaped" (Vauchez 2008, 129). De Gaulle could not have anticipated the degree to which law 
- far from remaining a sovereigntist chew-toy - has come to constitute the federal heart of a nascent transnational polity.

What Vauchez highlights is that French lawyers and their counterparts abroad were not destined to political decline and market capture, as Karpik, who devoted little attention to European integration, had contended. The "judicial construction of Europe," as Stone Sweet called it (Stone Sweet 2004), was a political opportunity for attorneys to become transnational brokers and accrue a new symbolic capital "at the intersection of the different levels (national, transnational) and sectors (administrative, political, judicial, economic, academic)" (Vauchez 2015, 104). Even the business bar that Karpik saw as apolitical proved anything but. For instance, when Cleary Gottlieb became the first American corporate law firm to open offices in Paris and Brussels in 1949 and 1960, respectively, it was because one of its founders - George Ball - was an intimate friend of Jean Monnet's and was so committed to doing his part to make a "United States of Europe" possible that the FBI described his law firm as an "acting agent" of the European Community (DiLeo 1991, 28; Flood 2007, 46; Vauchez 2015, 63-65). That proponents of European integration would indeed come to "think" of their project in terms of law (Bailleux 2012) - and would self-consciously emulate the role of law and courts in the development of the United States - was no accident: It was a legitimation strategy spearheaded by lawyers, for whom European integration represented a new political raison d'être: Reforming the French state in order to build a new transnational state.

French lawyers took a leading role in forging "communities of international litigators" and pushing national judges to see themselves not as subservient to the state, but as outposts of a nascent transnational polity (Vauchez 2014; Pavone 2019a). Consider the case of Paul-François Ryziger, a leading Europeanist lawyer on the Cassation bar, who regularly corresponded with a Brussels-based counterpart - Michel Gaudet - who directed the European Commission's legal service in the 1960s. Drawing on the "American historical experience," both wanted the ECJ to play a "statesmanlike job" and, through an alliance with national courts, to "fully contribute as an institution to the construction of a federal Europe" (Rasmussen 2012,378-385; Bailleux 2013, 360-361). Ryziger put his money where his mouth was. As a litigator, he vigorously sought out open-minded judges - like Adolphe Touffait on the Paris Court of Appeal - and stubbornly pushed them to refer cases to the ECJ to challenge domestic laws. He drafted the orders of referral to the European Court for French courts who lacked knowledge of European law, and he brokered dinners between ECJ judges at the Council of State such that they could smooth out their differences (Bernier 2018, 129-131, 148-149). He also tried to rally the French public against de Gaulle, excoriating the General in a 1965 editorial in Le Monde: "Does 
French grandeur mean splendid isolation for our Head of State?... the immense majority of Frenchmen want the creation of a great European ensemble, which they already consider to be their homeland. This is why they cannot but stand up against the monstrous counter-truths accumulating today" (Ryziger 1965). We do not know the extent to which the broader French public heeded Ryziger's call, but we know for certain that French officials paid very close attention: Internal government correspondence described Ryziger as part of a militant group of lawyers who "knew the inclinations of the ECJ very well and never ceased to push French judges to exploit them" against the state (Bernier 2018, 202).

These transnationally-oriented lawyers - whom Vauchez (2008) calls "Euro-lawyers" - did not rely on personal networks and individual entrepreneurship alone. They also sought to build what they described as an "army of European jurists, [a] vanguard whose loyal feats" could chip away at the obstinacy of European states (Vauchez 2015, 104). They thus founded the first cross-national lawyers' associations in Europe, like AJE (Association des Juristes Européens) and FIDE (Fédération International pour le Droit Européen) in 1961. Now, there is some debate as to whether these networks truly managed to constitute a "private army of the [European] Communities" (Vauchez 2015, 88) and full-fledged "jurist advocacy movement" (Alter 2016) or whether they remained a patchwork of loose networks (Bernier 2012; Byberg 2017). To the extent that Gaullist state officials vigorously resisted bureaucratic reform, the impact of Euro-lawyer associations remained "contained" (Conant 2002). But we should not underestimate how these efforts were spearheaded by lawyers who knew they were engaged in a political struggle for the longue durée. The co-founder of the AJE, LiseFunck Brentano, was another prolific mobilizer of French courts (Pavone 2019a, 155-232) convinced of "the fundamental role that the law plays in uniting Europe." ${ }^{2}$ Like Ryziger, she published in Le Monde throughout her career to defend the ECJ from sovereigntist attack. For instance, when in 1980 famed French constitutional law professor Maurice Duverger railed against a "gowvernement des judges européens" reminiscent of "the soviet judges of Leninist times" (Duverger 1980), Funck-Brentano published a strongly-worded rebuttal: "Isn't accusing the [European] Court of being 'biased' without citing any case illustrating this critique a sign of the very same 'bias' for which the author charges the Court?" (Funck-Brentano 1980).

This combination of initiatives - public advocacy, strategic litigation before national courts, and transnational networking - supplied the fuel for the piecemeal reform of the French state: Without it, neither Alter's "inter-court competitions" nor Stone Sweet's "judicial construction of Europe" would have gotten off the ground (Pavone 2018; 2019a; 2019b). But the broader point is that it was 
the conjunction of lawyers' legal politics on the one hand, and judges' transnational collaborations on other hand, that began eroding the obstinate French state's claims to executive supremacy and unitary authority. Lawyers' position as brokers nestled between civil society, the state, and international institutions, combined with judges' appeals to a pan-European rule of law, proved a remarkable force of political development. Since the European Union is, first and foremost, a liberal polity forged through a multi-level network of courts (Kelemen 2011; Pavone and Kelemen 2018), the French case exemplifies what happens when new legal opportunity structures enable lawyers' domestic struggles for political liberalism to spill across state borders. Sociologists have pounced on this insight to probe how state reform is induced processes of "transnational legal ordering" beyond Europe (Shaffer 2012; Block-Lieb \& Halliday 2017), and to identify how lawyers mobilize international networks to push for domestic governance reforms, even in authoritarian states (Liu 2013; Liu \& Halliday 2016). Yet to date, this body of work remains marginal in the field of comparative politics (for a personal account of this marginalization, see Volcansek 2019, ix-x). Yesterday's shortcomings, however, can become tomorrow's opportunities for novel comparative research.

\section{From the Micro-World of Legal Politics to the Macro-World of Comparative Politics}

The findings in this article serve as a springboard to a research agenda already-in-the-making, one that begs comparative political scientists to take greater stock of recent advances in law and politics research. For instance, over the past two decades judicial politics scholars have abandoned their field's previously US-centric origins to wrestle with core comparative debates about the evolution of modern governance and the transformation of states. Consider one indicator of this advance: For the first 32 years of its existence, the American Political Science Association's (APSA) prize for best dissertation in public law was awarded exclusively to projects focusing on the American constitutional system. Yet since 1996, some ten awardees pursued explicitly comparative research. ${ }^{3}$ The resulting books have already made lasting contributions to comparative politics, exemplifying how greater sensitivity to legal actors can shed new light on processes of state-building, democratic and authoritarian governance, and institutional change (ex. Epp 1998; Moustafa 2007b; Staton 2010; Kapiszewski 2012; Massoud 2013). Yet this literature has yet to be fully "owned" by the field of comparative politics - perhaps because it tends to pursue in-depth analyses of single cases (or at most a couple of cases) and focuses on less visible forms of political struggle. ${ }^{4}$

Can the intensive analysis of a single case - with an eye to the intertwining of law and politics - yield theoretically fertile comparative insights about political order, modernity, and democratic self- 
governance? This question lies at the core of this issue of French Politics (see Fredette, in this issue), and this article makes the case for an affirmative answer. That is, I have shown how a fresh look at the French historical experience can be mobilized to challenge an influential thesis about the resilience of centralized governance in modern states advanced by a leading scholar of comparative and international politics. More than any other political scientist of his generation, Stanley Hoffmann embodied the ability to leverage micro-level knowledge of a single case (France) to speak to macrolevel debates in political science (what Elgie, Grossman, and Mazur (2016) term the "French touch;" see Fredette, this issue). Indeed, his writings on continuity in French high politics greatly contributed to France being taken as exemplifying the path dependence of modern, unitary states - what I have labeled the "obstinate state" thesis. Yet by focusing our gaze on those actors that Hoffmann tended to dismiss - lawyers and judges - we can flip his "obstinate state" thesis on its head and expose all the fascinating contradictions, "intercurrences," and "disharmonies" of political development (Orren \& Skowronek 1996; Jacobsohn 2010, 1-33). It turns out that the French case also represents a story of how bottom-up legal politics and judicialization can become vectors of political liberalism and state transformation in those places where you would least expect it: In civil law countries without a history of judicial review, in authoritarian regimes without regard for judicial independence, and in what appear to be monolithic states without much room for democratic self-governance.

To be sure, tracing the politics of lawyers and judges can be a challenge. For one, legal professionals form what Tocqueville (2003, 254-255) termed "a party which is but little feared and scarcely perceived:" They are indeed less conspicuous than military generals who mount coups, public officials who campaign in elections, or political activists who lead democratic revolutions. Legal actors also have a nagging tendency to transgress the primary unit of analysis in comparative politics (the state itself) by becoming transnational "boundary-blurrers" (Liu 2013, 684-685). Finally, legal actors are not always successful in bending states to their will: de Gaulle's belief in the subservience of law to executive power is hardly obsolete, and Hoffmann's obstinate state is hardly dead. And yet, in the greatest tribute that vice paid to virtue, today even those who seek to entrench unitary and authoritarian states from Hungary to Venezuela weaponize legal politics and appeal to the force of law (Scheppele 2018). If France exemplifies the surprising role of lawyers and judges in shaping the fate of the modern state, then the world is arguably becoming more French. Comparative political scientists cannot do without taking stock of these developments, and the field of comparative politics only stands to be enriched if legal actors are afforded greater pride of place within the heart of the enterprise. 
${ }^{1}$ Case C-26/62, N.V. Algemene Transport- en Expeditie Onderneming Van Gend \& Loos v. Nederlandse Administratie der Belastingen [1963], ECR 1; Case C-6/64, Flaminio Costa v. ENEL [1964], ECR 1141.

${ }^{2}$ Karen Alter interview with Lise Funck-Brentano, May 26, 1994. On file with author.

${ }^{3}$ See: https://www.apsanet.org/PROGRAMS/APSA-Awards/Edward-S-Corwin-Award

4 To cite just one of many indicators of this marginalization, the American Political Science Association's (APSA) award for best dissertation in comparative politics - the Gabriel Almond Award - has never been awarded to a thesis dealing with law, courts, or legal actors as central themes. See: https://www.apsanet.org/almondaward 


\section{References}

Alter, Karen. 1996. "The European Court's Political Power." West European Politics 19 (3): 458-487.

Alter, Karen. 2001. Establishing the Supremacy of European Law: The Making of an International Rule of Law in Europe. New York, NY: Oxford University Press.

Alter, Karen, and Laurence Helfer. 2017. Transplanting International Courts: The Law and Politics of the Andean Tribunal of Justice. New York, NY: Oxford University Press.

Bailleux, Julie. 2012. Penser l'Europe par le Droit. Ph.D. Dissertation, Université Paris 1 PanthéonSorbonne.

Bell, David. 1992. "The "Public Sphere," the State, and the World of Law in Eighteenth-Century France." French Historical Studies 17 (4): 912-934.

Bell, John. 2000. "Review of French Lawyers: A Study in Collective Action, 1274-1994." International and Comparative Law Quarterly 49 (3): 748-749.

Berger, Suzanne. 2019. "'Decline or Renewal': France and the Hoffmann Paradigm." French Politics 7 (3/4): 391-402.

Bernier, Alexandre. 2012. "Constructing and Legitimating: Transnational Jurist Networks and the Making of a Constitutional Practice of European Law, 1950-70." Contemporary European History 21 (3): 399-415.

Bernier, Alexandre. 2018. La France et le droit communautaire 1958-1981. PhD dissertation, University of Copenhagen.

Biland, Émilie, \& Rachel Vanneuville. 2012. "Government lawyers and the training of senior civil servants." International Journal of the Legal Profession 9 (1): 29-54.

Bleich, Erik. 2018. "Historical Institutionalism and Judicial Decision-Making: Ideas, Institutions, and Actors in French High Court Hate Speech Rulings." World Politics 70 (1): 53-85.

Block-Lieb, Susan, and Terence Halliday. 2017. Global Lawmakers: International Organizations in the Crafting of World Markets. New York, NY: Cambridge University Press.

Bourdieu, Pierre. 1986. "The Force of Law: Toward a Sociology of the Juridical Field." Hastings Law Journal 38: 814-854.

Brouard, Sylvain. 2010. "The Study of Judicial Politics in France." French Politics 8: 72-76.

Brouard, Sylvain. 2016. "Constitutional Politics: The French case and theory-building." In The Oxford Handbook of French Politics, Elgie, Grossman, \& Mazur, eds. New York, NY: Oxford University Press.

Burrage, Michael. 1999."Escaping the Dead Hand of Rational Choice: Karpik's Historical Sociology of French Advocates." Law \& Social Inquiry 24 (4): 1083-1124.

Byberg, Rebekka. 2017. "A Miscellaneous Network: The History of FIDE, 1961-94." American Journal of Legal History 57 (2): 142-165.

Cichowski, Rachel. 2007. The European Court and Civil Society: Litigation, Mobilization, and Governance. New York: Cambridge University Press.

Conant, Lisa. 2002. Justice Contained: Law and Politics in the European Union. Ithaca, NY: Cornell University Press.

Darnton, Robert. 2010. Poetry and the Police: Communication Networks in Eighteenth-Century Paris. Cambridge, MA: Harvard University Press.

Davies, Bill, and Morten Rasmussen. 2012. "Toward a New History of European Law." Contemporary European History 21 (3): 305-318.

DiLeo, David. 1991. George Ball, Vietnam, and the Rethinking of Containment. Chapel Hill, NC: University of North Carolina Press. 
Doyle, Michael. 2009. "Differentiating Compliance with International Law: Stanley Hoffmann's threefold distinction." French Politics 7 (3/4): 423-431.

Duverger, Maurice. 1980. "Le gouvernement des juges européens." Le Monde, September 20.

Epp, Charles. 1998. The Rights Revolution: Lawyers, Activists, and Supreme Courts in Comparative Perspective. Chicago, IL: University of Chicago Press.

Featherstone, Kevin. 1994. "Jean Monnet and the 'democratic deficit' in the European Union." Journal of Common Market Studies 32 (2): 149-170.

Flood, John. 2007. "Lawyers as Sanctifiers: The Role of Elite Law Firms in International Business Transactions." Indiana Journal of Global Legal Studies 14 (1): 35-66.

Fredette, Jennifer. Forthcoming. "France as a Case: Exploring Modernity, Rationality, and Democratic Self-Rule Through Thick Description and Historical Institutionalism." French Politics (this issue).

Funck-Brentano, Lise. 1980. "La prétendue "partialité" de la Cour de Luxembourg." Le Monde, October 20.

Ginsburg, Tom. 2003. Judicial Review in New Democracies: Constitutional Courts in Asian Cases. New York, NY: Cambridge University Press.

Halliday, Terence, and Lucien Karpik. 1997. Lanyers and the Rise of Western Political Liberalism: Europe and North America from the Eighteenth to Twentieth Centuries. New York, NY: Oxford University Press.

Halliday, Terence, Karpik, Lucien, and Malcolm Feeley. 2007. Fighting for Political Freedom: Comparative Studies of the Legal Complex and Political Liberalism. Portland, OR: Hart.

Hirschl, Ran. 2008a. "The Judicialization of Politics." In Goodin, ed., The Oxford Handbook of Political Science. New York, NY: Oxford University Press.

Hirschl, Ran. 2008b. "The Judicialization of Mega-Politics and the Rise of Political Courts." Annual Reviews of Political Science 11: 93-118.

Hoffmann, Stanley. 1966. "Obstinate or Obsolete? The Fate of the Nation-State and the Case of Western Europe." Daedalus 95 (3): 862-915.

Hoffmann, Stanley. 1987. "Mitterand's Foreign Policy, or Gaullism by Any Other Name." In Ross and Hoffmann, eds. The Mitterand Experiment: Continuity and Change in Modern France. New York, NY: Oxford University Press.

Hoffmann, Stanley. 1991. "A Retrospective on World Politics." In Ideas and Ideals, Miller \& Joseph Smith, eds. New York, NY: Routledge.

Howe, Richard Herbert. 1978. "Max Weber's Elective Affinities: Sociology within the Bounds of Pure Reason." American Journal of Sociology 84 (2): 366-385.

Jacobsohn, Gary. 2010. Constitutional Identity. Cambridge, MA: Harvard University Press.

Kagan, Robert. 2001. Adversarial Legalism: The American Way of Law. Cambridge, MA: Harvard University Press.

Kapiszewski, Diana. 2012. Kapiszewski, Diana. High Courts and Economic Governance in Argentina and Brazil. New York, NY: Cambridge University Press.

Karpik, Lucien. 1988. "Lawyers and Politics in France, 1814-1950: The State, the Market, and the Public." Law \& Social Inquiry 13 (4): 707-736.

Karpik, Lucien. 1995. Les avocats: entre l'État, le public et le marché, XIIIe-XXe siècle. Paris: Gallimard.

Karpik, Lucien. 1999. French Lawyers: A Study in Collective Action, 1274-1994. New York, NY: Oxford University Press.

Kelemen, R. Daniel. 2011. Eurolegalism: The Transformation of Law and Regulation in the European Union. Cambridge, MA: Harvard University Press.

Kelemen, R. Daniel, and Tommaso Pavone. 2018. "The Political Geography of Legal Integration: Visualizing Institutional Change in the European Union." World Politics 70 (3): 358-397. 
Ledré, Charles. La presse à l'assaut de la monarchie, 1815-1848. Vol. 12. A. Colin, 1960.

Liu, Sida. 2013. "The Legal Profession as a Social Process." Law \& Social Inquiry 38(3): 670-693.

Liu, Sida, and Terence Halliday. 2016. Criminal Defense in China: The Politics of Lanyers at Work. New York, NY: Cambridge University Press.

Massoud, Mark. 2013. Law's Fragile State: Colonial, Authoritarian, and Humanitarian Legacies in Sudan. New York, NY: Cambridge University Press.

Miller, Linda, and Michael Joseph Smith. 1991. Ideas and Ideals: Essays on Politics in Honor of Stanley Hoffmann. New York, NY: Routledge.

Moravcsik, Andrew. 1991. "Negotiating the Single European Act: National interests and conventional statecraft in the European Community." International Organization 45 (1): 19-56.

Moravcsik, Andrew. 1994. "Why the European Union Strengthens the State." Paper presented at the Annual Meeting of the American Political Science Association, New York, NY, 1-79.

Moravcsik, Andrew. 1998. The Choice for Europe: Social Purpose and State Power from Messina to Maastricht. Ithaca, NY: Cornell University Press.

Moustafa, Tamir. 2007a. "Mobilising the law in an Authoritarian State: The Legal Complex in Contemporary Egypt." In Fighting for Political Freedom, Halliday, Karpik, and Feeley, eds. Portland, OR: Hart.

Moustafa, Tamir. 2007b. The Struggle for Constitutional Power: Law, Politics, and Economic Development in Egypt. New York, NY: Cambridge University Press.

Neville Brown, Lionel, Bell, John, and Jean-Michel Galabert. 1998. French Administrative Law, 5th ed. Oxford, UK: Clarendon Press.

Orren, Karen, and Stephen Skowronek. 1996. "Institutions and Intercurrence: Theory building in the fullness of time." Nomos 38: 111-146.

Pavone, Tommaso. 2018. "Revisiting Judicial Empowerment in the European Union: Limits of Empowerment, Logics of Resistance." Journal of Law \& Courts 6 (2): 303-331.

Pavone, Tommaso. 2019a. The Ghostwriters: Lawyers and the Politics Behind the Judicial Construction of Europe. Ph.D. Dissertation, Princeton University.

Pavone, Tommaso. 2019b. "From Marx to Market: Lawyers, European Law, and the Contentious Transformation of the Port of Genoa." Law \& Society Review 53 (3): 851-888.

Pavone, Tommaso and R. Daniel Kelemen. 2019. "The Evolving Judicial Politics of European Integration: The European Court of Justice and National Courts Revisited." European Law Journal 25 (4): 352-373.

Perez-Perdomo, Rogelio. 2007. "Lawyers and Political Liberalism in Venezuela." In Fighting for Political Freedom, Halliday, Karpik, and Feeley, eds. Portland, OR: Hart.

Pierson, Paul. 1994. Dismantling the Welfare State? Reagan, Thatcher, and the Politics of Retrenchment. New York, NY: Cambridge University Press.

Pierson, Paul. 2000. "Increasing Returns, Path Dependence, and the Study of Politics." American Political Science Review 94 (2): 251-267.

Rasmussen, Hjalte. 1986. On Law and Policy in the European Court of Justice. Boston: Martinus Nijhoff.

Rasmussen, Morten. 2012. "Establishing a Constitutional Practice of European Law: The History of the Legal Service of the European Executive, 1952-65." Contemporary European History 21 (3): 375-397.

Rueschemeyer, 1986. "Comparing Legal Professions Cross-Nationally: From a Professions-Centered to a State-Centered Approach." American Bar Foundation Research Journal 11 (3): 415-446.

Ryziger, Paul-François. 1965. "Europe et Grandeur Française." Le Monde, July 7.

Sarat, Austin, and Stuart Scheingold. 2006. Cause Lamyers and Social Movements. Stanford, CA: Stanford University Press. 
Saurugger, Sabine. 2016. "The Europeanization of Public Policy in France: Actor-Centered Approaches." In Elgie, Grossman, and Mazur, eds., The Oxford Handbook of French Politics. New York, NY: Oxford University Press.

Scheingold, Stuart. 1999. "Taking Weber Seriously: Lawyers, Politics, and the Liberal State." Law \& Social Inquiry 24 (4): 1061-1081.

Scheppele, Kim Lane. 2018. "Autocratic Legalism." The University of Chicago Law Review 85 (2): 545-584.

Shaffer, Gregory. 2012. Transnational Legal Ordering and State Change. New York, NY: Cambridge University Press.

Staton, Jeffrey. 2010. Judicial Power and Strategic Communication in Mexico. New York, NY: Cambridge University Press.

Stern, Rachel. 2011. Environmental Litigation in China: A Study in Political Ambivalence. New York, NY: Cambridge University Press.

Stone, Alec. 1989. "In the Shadow of the Constitutional Council: The 'juridicisation' of the legislative process in France." West European Politics 12 (2): 12-34.

Stone, Alec. 1992. The Birth of Judicial Politics in France: The Constitutional Council in Comparative Perspective. New York, NY: Oxford University Press.

Suleiman, Ezra. 1974. Politics, Power, and Bureaucracy in France: The Administrative Elite. Princeton, NJ: Princeton University Press.

Tam, Waikeung. 2013. Legal Mobilization under Authoritarianism: The Case of Post-Colonial Hong Kong. New York, NY: Cambridge University Press.

Tocqueville, Alexis de. 2003 [1862]. Democracy in America, Vols. I \& II. New York, NY: Barnes \& Noble Books.

Vail, Mark. 2004. "The Myth of the Frozen Welfare State and the Dynamics of Contemporary French and German Social-Protection Reform." French Politics 2: 151-183.

Vauchez, Antoine. 2008. "The Force of a Weak Field. Law and Lawyers in the Government of Europe." International Political Sociology 2(2): 128-144.

Vauchez, Antoine. 2014. "Communities of International Litigators." In The Oxford Handbook of International Adjudication. eds. by Cesare Romano, Karen Alter, and Yuval Shany, New York, NY: Oxford University Press.

Vauchez, Antoine. 2015. Brokering Europe: Euro-Lawyers and the Making of a Transnational Polity. New York, NY: Cambridge University Press.

Vauchez, Antoine, and Bruno de Witte. 2013. Lanyering Europe: European Law as a Transnational Social Field. Portland, OR: Hart.

Volcansek, Mary. 2019. Comparative Judicial Politics. New York, NY: Rowman \& Littlefield.

Weber, Eugen. 1976. Peasants into Frenchmen: The Modernization of Rural France, 1870-1914. Stanford, CA: Stanford University Press.

Word Count: 8387

Date of Manuscript: May 22, 2020; Revised September 8, 2020 